\section{廃棄物最終処分場の 再生技術の現状と課題}

\section{1.はじめに}

20世紀型の大量生産・消費・廃棄から循環型社 会へのパラダイムシフトは, 最終処分場に対して も大きな影響を投げかけている，とはいえ最終処 分される廃棄物がなくなる訳ではない（環境省で は平成 22 年までに 9 年の埋立量の半分に削減する 目標が示されている)。そうであれば, 廃棄物最 終処分場の整備と適切な運営は, むしろ循環型社 会に必要不可欠な基盤施設と位置づける必要があ る.ところが，埋立構造や埋立廃棄物に対する住 民の不安や事業者に対する不信感等により, 地域 住民との合意形成が難しく，新たな最終処分場の 立地が困難になってきており, 最終処分場の確保 に不安を抱いている地方自治体も少なくない。こ うした状況下，平成14年に環境省では新たに最終 処分場の容量増加政策として, “最終処分場の再 生, ルネサンス”補助事業が立ち上げられた。

以上の現状を踏まえて，本報告では近年注目さ れている“最終処分場の再生”についてその技術 システムのあり方, 課題, 技術的現状を概観する.

\section{2. 最終処分場の再生とは}

最終処分場の再生とは, 狭義には過去に埋め立 てられた埋設物（ごみや覆土材など）を掘り起こ した後, 選別および熱処理等減容・安定化処理を 行い, 最終処分場を再び利用可能な状態に復元す ることをいう，処分場の再生の目的は，掘削・減 容化による処分場の埋立容量の増加あるいは延命 化であるが，環境污染防止対策が不十分な過去の 不適正処分場跡地の修復技術としても注目されて いる。

*国立環境研究所 Yuzo INOUE

\section{3．最終処分場を巡る現状と問題点}

平成12年度における一般廃棄物の総排出量は, 5,236 万 $\mathrm{t} ， 1$ 人 1 日当たり $1,132 \mathrm{~g}$ であり, 前年 度に比べて僅かに増加している，総ごみ処理量の 中で, 中間処理されるごみ量4,678万 $\mathrm{t}$ のうち焼 却される量は4,030万t（值接焼却率：77.4\%), 最終処分量は直接埋立量308万 $\mathrm{t}(5.9 \%)$ と中間 処理残椬量743万 $\mathrm{t}(14.3 \%)$ を合わせて 1,051 万 $\mathrm{t}$, 毎年大凡 4 \%減少を続けている。最終処分場の施 設総数は平成 12 年現在 2,077 施設, 総残余容量は 1 億 $5,700 \mathrm{~m}^{3}$, 残余年数は全国平均で 12 年, 首都 圈が12年，近畿圈が9.5年と比較的余裕があるよ うな印象を受けるが, これらの数值は都道府県の 残余年数の平均であり，市町村ごとに大きく異 なっている. 残余容量が逼迫し, 埋立地確保に不 安を抱いている自治体も少なくない.

一方, 産業廃棄物の排出量は, ほぼ横ばい状態 で平成 12 年度は 4 億 600 万 $\mathrm{t}$ である。最終処分量 は，近年の社会状況を反映して年間7.8\%の割合 で減少しているものの，その量は 4,500 万 $\mathrm{t} に も$ 及んでいる．最近の処分場の施設整備状況をみる と, 平成13年 4 月時点において 2,717 施設（遮断 型：41, 安定型 : 1,643, 管理型 : 1,033) があり, 埋立残余容量は 1 億7,600万 $\mathrm{m}^{3}$ となっている，新 設処分場は平成11年から極端に少なくなっている が，処分量の減量化により全国レベルではむしろ $3 \sim 4$ 年へと漸増している，ところが首都圈や近 畿圈のような大都市圈では $1 \sim 2$ 年という状況が 起こっている. 事態を重く見た自治体では既存埋 立地の延命化や再生に乗り出すところ（亀山市, 諫早市, 高砂市, 安城市など) も現れ始めている.

ところで, 平成 9 年法改正以前には最終処分場 の廃止制度がなく, 埋立終了後は廃止措置のみで 明確な規定はなく，その後の施設の管理状況が不 明なものが少なくない. わが国の一般廃棄物最終 処分場の総数は, 平成 6 年の時点で2,392ヶ所と なっている. しかし，この数字は閉鎖後の管理状 況の不備もあり, 実数が明らかでない. 樋口ら ${ }^{1)}$ は, 処分場施設総数を 3,500 施設以上と推計して いる，さらに平成 5 年度版施設年報 ${ }^{2)}$ で調査した 2,313 施設のうち, しゃ水工のない施設が 1,538 施 
設（67\%）と報告された。ただし，平成 9 年に旧 厚生省から不適正処分場の恐れの指摘を受けた処 分場 (公表) は, その後大部分は改善措置がなさ れている，一方，産業廃棄物の管理型最終処分場 は，同じく樋口らによれば過去20年間で約 2,000 施設(供用1,100，閉鎖／廃止900) と推定している.

最終処分場における環境污染リスクも重要な問 題である．上記の不適正処分場の指摘施設の中で 約 1 割の 42 施設で基準超過項目は, 大部分の施設 は CODMnであったが，Pb28施設，As 7 施設， 1,2-ジクロロエタン 2 施設, $\mathrm{T}-\mathrm{Hg}, \mathrm{Cd}$, シアン, シマジン 1 施設であった. ダイオキシン類も任意 報告で埋立地内保有水等に高濃度検出が示され た。また，可燃性ガス（メタン）や有害ガス（硫 化水素など）の発生が報告されている，以上のよ うに古い処分場についてはしゃ水工もなく，不適 正処分場の指摘がなされたところも少なくなく，将 来的に適切な環境污染防止対策が必要となろう。

\section{4. 再生技術の現状・課題}

最終処分場の再生は, 埋設廃棄物を掘り起こし (攪乱し), 結果的には再び大気に晒し，内部に閉 じこめられていた有害物質や悪臭物質を容易に周 辺環境に拡散・輸送・移動させる可能性を著しく 高める行為である. 特に, 覆土材料などの土や安 定化物，プラスチックや未分解の紙類・木質など の可燃物あるいは金属を分離・処理する工程で粉 塵，VOC あるいは悪臭物質等を発生させる可能 性がある，粉塵にはダイオキシン類等の微量有害 化学物質や有害重金属を含む可能性も高い. 以上 のように再生事業においては, 一連の再生工程に おける環境影響防止が最も重要な課題となる。

一方，再生事業フローの途中において最終処分 場の特性によっては現状の技術レベルでは封じ込 めをすることが最もよい場合もある（再生事業の 中止 $\rightarrow$ 修復事業への転換）し，予めある程度埋立 層内部を通気等により安定化した後, 掘削工程や 分離工程に入ることも考えられる。したがって， 最終処分場の再生では，掘り起こし工程の前に処 分場の再生ニーズ・目的の確認, 最終処分場の性 状把握，その後にニーズ・目的合致性の評価（現 状維持, 封じ込め, 資源化·再生, 溶融・再生等) および工程選択を行う一連の事前調査・計画策
定・評価が必要になる。

再生事業は，事業性評価と住民理解の社会事業 であり，総合技術システムとして位置づける必要 がある，以後，技術システムを構成する重要な技 術を示す，なお，埋立地再生の技術ステップにつ いては，わが国では埋立地再生総合技術研究会の 平成14年度報告書 ${ }^{3)}$ およびブレント・イナンチ, 井上ら ${ }^{4)}$ の「諸外国の最終処分場再生の現状」に レビューされているので参照されたい.

（1）埋立地の特性把握技術

基礎・本調査からなり, 本事業を推進や工程選 択を行うための極めて重要な技術である．基礎調 査とは，不適正処分場や旧構造基準処分場の特性 化情報の把握, 埋設埋立物の処理方法の検討, 掘 削による作業環境や周辺環境影響評のための調査 である。

また，本調査では目的事業の効果（埋設廃棄物 の物性把握, 容量増加率, 延命化効果), 選別, 運搬等再生事業工程に伴う作業環境や周辺環境へ の影響を評価するための調査技術である。これら の技術には埋立履歴調査手法, 埋設廃棄物探査手 法, 埋設廃棄物安定化把握手法, 埋設廃棄物性状 把握手法等の技術がある。ボーリングやテスト ピットによる埋立層直接把握技術あるいは比抵抗 探査や電磁探査技術のような間接的な埋立層把握 技術が利用されているが, 後者については最終処 分場の調査事例が少なく，その信頼性が今後の課 題である.

事業実施工程における作業環境や周辺環境影響 把握に関する技術に関しては，これも諸外国をも 含めてその実施例がそれほど多くはないが，北米 廃棄物協会 (SWANA） ${ }^{5)}$ は処分場再生に係る技 術上の基準を提案している。 またフロリダ州では 埋立地調査法としてテストピットを 5 エーカーに 1 個としている。井上ら ${ }^{6)}$ は，ボーリングバー調 査によるテストピット場所決定法を明らかにし た。一方，選別や運搬等における作業環境や周辺 環境への影響把握技術として, 交通・大気污染分 野の環境計測技術が利用可能である。また，埋設 廃棄物の性状を把握するためにテストピット掘削 ごみをスケルトンバケットやトロンメル, 磁力選 別機, 風力選別機等を用いて選別し, 埋立地ごと にその性状特性を把握する必要がある. 
(2) 掘削工程関連技術

掘削（掘り起こし）工程に関連する技術は, 既 に他の分野で実用化されている技術（土木施工技 術や鉱山掘削技術）が利用できるが，掘削物の性 状が大きく異なるので，作業性や効率に関する データを集積し, 技術改良の評価・検討が必要で あろう。関連技術としては，掘削現場が粉塵や VOC等周辺環境に対する影響を防止するために， 覆蓋技術や環境保全（作業環境における対策技術 や計測技術）が必要になる。これらの技術は既に 廃棄物の中間処理，特に破砕・資源化処理におい て技術開発されたものが利用可能である。

しかし, 硫化水素や酸欠ガスの発生, メタンな どの可燃性ガスの発生, ダイオキシン類の存在等 があり，モニタリングや対策処理技術，施工技術 の適法性の検討が必要である。また，処分場に よっては緊急性から非常に劣悪な作業環境での掘 削作業が強いられる場合も想定される。このよう な場合を想定して遠隔操作重機やロボット型重機 等の開発も必要になる。

（3）輸送・選別工程における技術

廃棄物の選別は，処分場ごとにその埋設物の性 状が異なり, 性状に応じた機種や仕様選定技術が 必要になる。また，後工程になる中間処理施設の 能力や処理方式にもマッチングが必要であり，フ レキシビリティの高いいろいろな組み合わせを検 討する必要がある。破砕・選別工程においては粉 塵対策が最も重要な課題となる。特に，ダイオキ シン類対策のために湿潤状態や半湿式による選別 技術の検討が必要であるが，既に土䁃污染対策技 術としていくつかの湿式法が開発されている。こ れらの技術は，前掲の文献1）および3）で検討さ れているので参照されたい.

運搬工程ではダイオキシン類などの有害物質や 悪臭を放つごみを運搬するのであるから，場外污 染防止対策技術や運搬途中での拡散や散乱による 環境污染防止対策等の検討が必要である。これら の技術は，焼却灰や土壤污染対策において実証さ れた技術が利用可能であるが，実証研究の必要が ある。

（4）中間処理技術

事業対象となる埋設廃棄物は, 処分場により著 しく異なり, 可燃物に不燃物や土砂等が混ざった
もので，埋立廃棄物とは物性的に著しく異なった 組成を示す．前項の選別技術により既存中間処理 施設に調和した組成に変えることもあるが，溶融 技術のようにそのまま処理可能な場合もある。た だし，既存施設を利用する場合には，混合率の把 握が実施レベルで必要になる。

（5）再生埋立地整備技術

埋立地再生事業の主な目的は, 埋立地を再生し, 延命化を図ることである，その場合，周辺住民の 受容可能な施設とするために新構造基準との整合 性，跡地利用促進など地域振興のための斬新な社 会システム開発が必要となる。

\section{5.おわりに}

廃棄物最終処分場の再生は，処分場の残余容量 が逼迫しているわが国においては，技術開発に緊 急を要する課題である。本稿では，処分場再生の 目的や意義，わが国の事情を明らかにするととも に，その技術の現状や課題を明らかにした，本稿 が今後のわが国の最終処分場の再生事業の発展に 貢献できれば幸いである。

なお，本稿は福岡大大学院樋口先生および(財)日 本環境衛生センター藤吉環境工学部長がまとめ た，平成14年度廃棄物処理等科学研究報告書「埋 立地再生総合技術システムの開発」，ならびに(財) 日本環境衛生センターが中心となって作った埋立 地再生総合技術研究会の研究成果「埋立地再生総 合技術に係る研究」平成14年度報告書を参考とし た．記して謝意を述べたい。

\section{参考文献}

1 ）樋口壯太郎・藤吉秀明：埋立地再生総合技術システムの 開発, 平成14年度廃棄物処理等科学研究費研究報告書 (2003，3)

2 ）平成 5 年度版 施設年報，環境産業新聞社

3) 埋立地再生総合技術研究会・(財)日本環境衛生センター： 「埋立地再生総合技術に係る研究」平成14年度報告書 (2003. 3)

4 ) ブレント・イナンチ, 石垣智基, 山田正人, 井上雄三 : 欧米諸国における最終処分場再生の現状，特集諸外国の 廃棄物最終処分場の現状，環境技術，Vol.32, No.6, pp.594-600 (2003)

5 ) SWANA: Landfill Reclamation; Manual of Practice and Procedure, The Landfill Reclamation Task Force, SWANA Publicaiton No. GR-D 2245 (1977)

6 ) 井上雄三, Bulent Inanc 他：ボーリングバー埋立ガス測 定法による最適なテストピット位置選定法について（内 部資料) 